\title{
Kinerja Pemerintah Kabupaten Kayong Utara Pasca Pemekaran Daerah
}

\author{
Rizky Darmawan ${ }^{a} *$ \\ ${ }^{a}$ Biro Pemerintahan Setda Prov. Kalimantan Barat, Pontianak, Kalimantan Barat
}

\section{INFORMASI ARTIKEL}

\section{Article history:}

Dikirim tanggal: 11 Maret 2019

Revisi pertama tanggal: 17 Juni 2019

Diterima tanggal: 30 Juli 2019

Tersedia online tanggal: 31 Agustus 2019

Keywords: decentralization, regional autonomy, regional expansion, performance

\begin{abstract}
This study uses a qualitative approach, which aims to describe and analyze the performance of the Kayong Utara Regency after it was expanded in 2007 by optimizing the role and function of the government in the regional expansion. The results of the study show that the expansion of the Kayong Utara Regency was formed by maximizing the DPRD initiative's rights mechanism. Furthermore, after regional expansion, the economic performance and performance of public services in the Kayong Utara Regency always increase every year, while the financial performance of the Kayong Utara Regency is still low. Also, in optimizing the role and function of the government in regional expansion, Kayong Utara Regency implements it with various programs and activities. The program includes Pelayanan Administrasi Terpadu Kecamatan (PATEN) as an Integrated District Administrative Services, Establishment of Perusahaan Daerah Air Minum (PDAM) as a Regional Water Companies, free school policies and 10 Bachelor Programs per village.
\end{abstract}

\section{INTISARI}

Penelitian ini menggunakan pendekatan kualitatif, yang bertujuan untuk mendeskripsikan dan menganalisa kinerja Pemerintah Kabupaten Kayong Utara pasca dimekarkan pada tahun 2007 dengan mengoptimalkan peran dan fungsi pemerintah dalam pemekaran daerah. Hasil penelitian menunjukkan bahwa pemekaran Kabupaten Kayong Utara dibentuk dengan memaksimalkan mekanisme hak inisiatif DPRD. Selanjutnya, pasca pemekaran daerah, kinerja perekonomian dan kinerja pelayanan publik Kabupaten Kayong Utara selalu meningkat setiap tahunnya, sedangkan untuk kinerja keuangan Kabupaten Kayong Utara masih rendah. Selain itu, dalam mengoptimalisasikan peran dan fungsi pemerintah dalam pemekaran daerah, Kabupaten Kayong Utara melaksanakannya dengan berbagai program dan kegiatan. Program tersebut meliputi Pelayanan Administrasi Terpadu Kecamatan (PATEN), Pembentukan Perusahaan Daerah Air Minum (PDAM), Kebijakan Sekolah Gratis dan Program 10 Sarjana per desa.

2019 FIA UB. All rights reserved.

\section{Pendahuluan}

Hierarki antar susunan pemerintahan dan antar pemerintahan daerah merupakan rangkaian yang dapat meningkatkan efisiensi dan efektifitas di dalam pelaksanaan otonomi daerah. Hierarki antar hubungan pemerintah itu sendiri menurut Adamolekun (1986:3) sebagai alat pentingnya menekankan dan secara aktif mendorong terjadinya kerjasama antar level 
pemerintahan yang berbeda. Selain itu, prinsip otonomi daerah merupakan prinsip otonomi seluas-luasnya dalam arti daerah diberikan kewenangan mengurus dan mengatur semua urusan pemerintahan sesuai dengan aturan yang berlaku. Seiring dengan prinsip itu, penyelenggaraan otonomi daerah harus selalu berorientasi pada peningkatan kesejahteraan masyarakat dengan selalu memperhatikan kepentingan dan aspirasi yang tumbuh dalam masyarakat. Perubahan mendasar terjadi ketika Undang-Undang Nomor 5 Tahun 1974 tentang Pemerintahan Daerah digantikan dengan Undang-Undang Nomor 22 Tahun 1999 tentang Pemerintahan Daerah.

Melalui kebijakan ini, diharapkan pola pengambilan keputusan makin pendek, sehingga proses pembangunan daerah dapat ditingkatkan secara lebih efektif dan efisien. Perubahan secara mendasar terjadi dari pemerintahan yang berkiblat ke sentralistik ke pembagian kewenangan kepada daerah (desentralistik). Perubahan tersebut memicu lahirnya konsep pemekaran daerah hampir diseluruh daerah termasuk di Provinsi Kalimantan Barat. Ratnawati (2009:11) mengemukakan bahwa kebijakan desentralisasi dan otonomi daerah pada masa reformasi merupakan kebijakan yang tepat untuk melakukan pemekaran daerah. Selanjutnya, Poerwadarminta (2005:82) mengemukakan bahwa pemekaran daerah merupakan "pemisahana suatu bagian wilayah yang merupakanr satu kesatuanr yang utuh menjadi beberapa bagian yang berdirir sendiri”.

Salah satu daerah yang dimekarkan menjadi Daerah Otonom Baru (DOB) diwilayah Provinsi Kalimantan Barat adalah Kabupaten Kayong Utara yang yang dibentuk dengan Undang-Undang Nomor 6 Tahun 2007 tentang Pembentukan Kabupaten Kayong Utara di Provinsi Kalimantan Barat. Alasan pemekaran tersebut dilatarbelakangi tiga faktor, yaitu (a) Sulitnya pembangunan baik dari aspek pembangunan infrastrukturnya maupun pembangunan sumber daya manusianya. Berdasarkan data Badan Pusat Statistik (BPS), angka rata-rata lama sekolah daerah induknya, yaitu Kabupaten Ketapang berada diangka 5,47 pada Tahun 2005 dan 6,09 pada Tahun 2007. Angka ini menunjukkan bahwa rata-rata tingkat pendidikan penduduk usia sekolah di Kabupaten Ketapang yang dapat menyelesaikan sekolah hanya sampai pada kelas 6 Sekolah Dasar (SD). (b) Luas wilayah Kabupaten Ketapang yang luasnya $\pm 35.808 \mathrm{Km}^{2}$ sulit membagi porsi APBD Kabupaten Ketapang untuk pembangunan pada 25 kecamatan, dengan kondisi APBD Kabupaten Ketapang kurang dari 1 Trilyun Rupiah. Berdasarkan data dari Badan Pengelola Keuangan dan Pendapatan Daerah (BPKAD) Kabupaten Ketapang bahwa pada Tahun 2005 jumlah APBD hanya 360 milyar dan pada Tahun 2007 berjumlah 697 milyar. (c) Rentang kendali pemerintahan, sehingga menghambat akses pelayanan publik ke masyarakat. Selain itu, berdasarkan Pearturan Presiden Nomor 131 Tahun 2015 bahwa Kabupaten Kayong Utara merupakan salah satu kabupaten yang berkategori sebagai daerah tertinggal di Indonesia, termasuklah kabupaten induknya, yaitu Kabupaten Ketapang.

Berdasarkan latar belakang tersebut, beberapa tujuan dari penulisan ini, yakni untuk (a) Proses pemekaran Kabupaten Kayong Utara; (b) Kinerja Pemerintah Kabupaten Kayong Utara pasca pemekaran daerah; dan (c) Optimalisasi peran dan fungsi pemerintah dalam pemekaran daerah.

\section{Teori}

\subsection{Otonomi Daerah}

Manan (1994:21) menyatakan bahwa otonomi mengandung arti kemandirian untuk mengatur dan mengurus urusan rumah tangganya sendiri. Selanjutnya hal-hal yang mendasari pada pengertian otonomi daerah adalah bahwa untuk memberdayakan masyarakat, menumbuhkan prakarsa dan kreativitas, meningkatkan peran serta masyarakat, mengembangkan peran dan fungsi Dewan Permusyawaratan Daerah (DPRD). Daerah kabupaten dan daerah kota berkedudukan sebagai daerah otonomi yang mempunyai kewenangan dan keleluasaaan untuk membentuk dan melaksanakan dasar menurut prakarsa dan aspirasi masyarakat (asas desentralisasi). Selanjutnya Domai (2011:2) menyatakan bahwa agar otonomi daerah dapat dilaksanakan sejalan dengan tujuan yang hendak dicapai, pemerintah wajib melakukan pembinaan dan pengawasan serta memberikan fasiitasi yang berupa pemberian peluang kemudahan bantuan.

Secara Teoritis Bird \& Vaillancourt sebagaimana dikutip Hamzah (2008) menyatakan bahwa tujuan otonomi daerah dibedakan atas tiga kategori utama, yaitu (a) Tujuan administrasi yang antara lain meliputi penciptaan efisiensi penyelenggaraan pemerintahan daerah termasuk di dalamnya peningkatan pelayanan publik; (b) Tujuan ekonomi yang antara lain untuk mempercepat proses pembangunan ekonomi didaerah guna mewujudkan kemakmuran bagi rakyat; dan (c) Tujuan politik yang antara lain untuk mempercepat proses demokratisasi ditingkat lokal/ kabupaten dan kota dan terciptanya akuntabilitas publik

\subsection{Desentralisasi}

Rondenelli sebagaimana dikutip Domai (2011:15) mengemukakan bahwa:

Desentralisasi berarti pemindahan atau penyerahan perencanaan, membuat keputusan atau otoritas manajemen dari pemerintah pusat dan perwakilannya kepada organisasi lapangan, unit-unit pemerintahan yang lebih rendah, badan hukum publik, penguasa wilayah luas maupun regional, 
para ahli fungsional ataupun kepada organisasi non pemerintah".

Desentralisasi memberikan alasan yang lebih kuat untuk meindahkan tanggung jawab perencanaan dan pelaksanaan kepada penguasa regional, pemerintah lokal dan propinsi. Selanjutnya Rondenelli sebagaimana dikutip Domai (2011:17) memberikan argumentasi bahwa desentralisasi merupakan (a) Pelaksanaan kebijakan pembangunan yang dibuat untuk menyelesaikan perkembangan dengan adil melalui kapasitas satuan reginal dan sub regional; (b) Membatasi pembatasan dan prosedur birokrasi yang terlalu tinggi; (c) Meningkatkan kesatuan nasional dan kekuasaan politik pemerintah dengan menyediakan mekanisme pada masyarakat untuk mengemukakan masalah mereka; (d) Menghasilkan koordinasi perencanaan dan pelaksanaan lokal yang lebih efektif; (e) Sebagai alat untuk meningkatkan efisiensi perwakilan pemerintah pusat; (f) Meningkatkan partisipasi penduduk dalam proses perencanaan pembangunan; (g) Memudahkan masuknya fasilitas dan program-program pemerintah dengan mengurangi pengawasan dari kalangan setempat terhadap kegiatan pembangunan; (h) Meningkatkan efisiensi pelayanan kepentingan pokok masyarakat dengan mengurangi biaya untuk pelayanan; dan (i) Meningkatkan flesibilitas perwakilan pusat, pegawai lapangan dan pemimpin lokal berkenaan dengan masalah khusus dalam sebuah daerah.

\subsection{Pemekaran Daerah}

Menurut Swianiewicz (2002:36) dalam artikelnya "Consolidation and fragmentation Siza od Local Government in Central and Eastern Europe"; menyatakan bahwa pemekaran wilayah dilihat sebagai faktor negatif disebagian besar negara Eropa Timur dan Tengah, dimana pelayanan pada pemeritah daerah yang kecil memiliki biaya unit yang lebih tinggi dan lemah untuk melaksanakan kebijakan pembangunan. Djayasinga (2006:44) juga menyebutkan bahwa permasalahan pemekaran wilayah yang sudah terjadi pada saat ini menunjukkan bahwa untuk meningkatkan kualitas layanan dan kesejahteraan masyarakat tidak harus dengan melakukan pemekaran wilayah karena pemekaran wilayah merupakan jangka panjang. Percepatan pembangunan jangka pendek dapat dilakukan dengan: (a) Pengelolaan anggara (APBD) dan kekuasaan yang baik; (b) Penataan pelayanan publik; dan (c) mendorong ruang partisipasi ekonomi masyarakat sebagai pilar pengelolaan demokrasi

Ferrazzi (2008) menuliskan beberapa alasan yang menyebabkan suatu negara aktif mengelola atau secara radikal mengadakan restrukturiasi territorial atau dalam kata lain adalah pemekaran wilayah adalah bahwa pemekaran wilayah lebih disebabkan adanya keuntungan dari administrasi pemerintah daerah yang menjadi lebih efisien. Sedangkan Riani (2012:20) juga menyatakan bahwa pemekaran wilayah memerlukan kajian terhadap faktor-faktor teknis kelayakan pembentukan daerah otonom seperti potensi daerah, kependudukan, rencana tata ruang wilayah pemekaran, kemampuan ekonomi dan keuangan daerah selama 10 tahun serta penilaian terhadap faktor lainnya seperti karakteristi tersendiri atas daerah pemekaran yang berupa kondisi budaya, potensi konflik, dan historis.

\subsection{Kinerja Pemerintah}

Menurut Dwiyanto et al., (2002:45), penilaian kinerja merupakan suatu kegiatan yang penting karena dapat digunakan sebagai ukuran keberhasilan suatu organisasi dalam mencapai tujuannya. Dengan melakukan penilaian terhadap kinerja maka upaya untuk memperbaiki kinerja bisa dilakukan secara lebih terarah dan sistematis. Sementara itu, Armstrong dan Baron dalam Wibowo (2007:2) mendefinisikan kinerja sebagai hasil pekerjaan yang mempunyai hubungan kuat dengan tujuan strategis organisasi sektor publik atau pemerintah dan kepuasan masyarakat.

Kinerja organisasi sektor publik juga ditunjukkan oleh bagaimana proses berlangsungnya kegiatan untuk mencapai suatu tujuan melalui program-program yang telah direncanakan sebelumnya. Seberapa jauh tujuan tersebut dapat dicapai, mencerminkan hasil kerja atau prestasi kerja dan dinyatakan sebagai kinerja organisasi. Terhadap hasil kerja atau prestasi kerja, perlu dilakukan evaluasi atas kinerja organisasi. Evaluasi atas kinerja organisasi akan dipergunakan untuk melakukan perbaikan kinerja organisasi dimasa yang akan datang.

\section{Metode Penelitian}

Penelitian ini menggunakan jenis penelitian deskriptif dengan pendekatan kualitatif yang bertujuan mendiskripsikan dan menganalisis secara komprehensif dan menyeluruh tentang kinerja Pemerintah Kabupaten Kayong Utara pasca pemekaran daerah. Sugiyono (2011:290) menerangkan bahwa "Penelitian Kualitatif sebagai suatu penelitian yang memandu peneliti untuk mengeksplorasi dan atau memotret situasi sosial yang akan diteliti secara menyeluruh, luas dan mendalam". Sugiyono (2011:287), menyebutkan bahwa untuk mempertajam penelitian, peneliti kualitatif harus menetapkan fokus. Fokus pada penelitian ini, yaitu:

a) Proses pembentukan Daerah Otonom Baru (DOB) Kabupaten Kayong Utara.

b) Kinerja Pemerintah Kabupaten Kayong Utara pasca pemekaran daerah dilihat dari:

- Kinerja perekonomian daerah;

- Kinerja keuangan pemerintah daerah; dan

- Kinerja pelayanan publik;

c) Optimalisasi peran dan fungsi pemerintah Kabupaten Kayong Utara dalam pemekaran daerah. 
Metode pengumpulan data dilakukan melalui wawancara dan studi dokumen pendukung. Informan kunci pada penelitian ini, yaitu Bupati Kayong Utara periode Tahun 2008-2018. Analisis data pada penelitian ini menggunakan model Analisis Data Interaktif dari Miles, Huberman dan Saldana (2014:8) yang meliputi tiga alur kegiatan, yakni: a) kondensasi data; b) penyajian data; dan c) penarikan kesimpulan.

\section{Hasil Penelitian dan Pembahasan}

\subsection{Proses Pembentukan Kabupaten Kayong Utara}

Mekanisme dalam proses pemekaran Daerah Otonom Baru (DOB) harus dipenuhi oleh Daerah Persiapan (Calon DOB), Daerah Induk dan Pemerintah Provinsi. Daerah tersebut memiliki tugas dan fungsinya sendiri terhadap proses pembentukan suatu Daerah Otonom Baru (DOB) dan saling berkesinambungan antara satu dengan yang lain.

\subsubsection{Daerah Persiapan}

Daerah persiapan sendiri memiliki tugas dalam mempersiapkan segala sesuatu yang menjadi persyaratan awal pembentukan suatu daerah otonom baru yang sudah diatur didalam aturan yang berlaku. Tugas daerah persiapan dapat dijabarkan sebagai berikut:

a) Menghimpun aspirasi masyarakat yang dinyatakan dengan surat pernyataan dukungan pembentukan Kabupaten Kayong Utara. Pada tahap ini, pemekaran Kabupaten Kayong Utara didukung penuh dari seluruh kecamatan dan desa yang menjadi cakupan wilayah pemekaran, yaitu sebanyak empat kecamatan dan 43 Desa. Bentuk dukungan tersebut ditampung dalam bentuk Surat Pernyataan yang ditandatangani oleh Aparat Desa, Tokoh Agama, Tokoh Masyarakat, Organisasi Masyarakat (ORMAS), Partai Politik;

b) Membentuk Panitia Persiapan Pembentukan Daerah Otonom Baru. Pada tahap ini, panitia persiapan tersebut dibentuk berdasarkan aspirasi dari masyarakat yang menginginkan adanya pembentukan daerah baru dengan maksud untuk mempercepat pembangunan di wilayahnya yang jauh tertinggal dari daerah-daerah lain. Selanjutnya panitia ini diberi nama Panitia Persiapan Pembentukan Kabupaten Kayong Utara (P3KKU) dibentuk pada tahun 2002 dengan Ketua Umum yaitu Abdul Samad dan bertugas untuk mempersiapkan segala sesuatu yang menjadi persyaratan awal dalam membentuk Daerah Otonom Baru (DOB); dan

c) Lobi Politik. Dalam pemekaran Kabupaten Kayong Utara, bentuk lobby politik yang harus dilakukan oleh Panitia Persiapan Pembentukan Kabupaten Kayong Utara (P3KKU) selaku organisasi masyarakat pengusung pemekaran adalah dengan aktif berkomunikasi baik dengan pihak eksekutif, yaitu
Bupati Ketapang dan pihak legislatif yaitu DPRD Kabupaten Ketapang. Berikut partai politik yang mendukung pembentukan Kabupaten Kayong Utara yaitu Partai Demokrasi Indonesia Perjuangan (PDIP), Partai Golongan Karya (GOLKAR), Partai Kebangkitan Bangsa (PKB), Partai Persatuan Pembangunan (PPP), Partai Amanat Nasional (PAN), Partai Bulan Bintang (PBB), Partai Keadilan dan Persatuan Indonesia (PKPI), Partai Republik, Partai Nasional Indonesia (PNI), Partai Bhineka Tunggal Ika dan Partai Demokrasi Indonesia (PDI).

\subsubsection{Daerah Induk}

Daerah Induk merupakan daerah asal pemekaran yang wilayahnya diambil untuk dijadikan daerah baru untuk tujuan tertentu. Dalam pembentukan daerah, tidak boleh mengakibatkan daerah induk menjadi tidak mampu menyelenggarakan otonomi daerah, dengan demikian baik daerah yang dibentuk dan daerah induknya harus mampu menyelenggarakan otonomi daerah sehingga tujuan pemekaran daerah dapat terwujud.

Tugas dari daerah induk dalam pemekaran daerah, yaitu:

a) Membentuk tim penelitian awal. Tim ini dibentuk pada tanggal 13 September 2002 dengan Surat Keputusan Bupati Ketapang Nomor 252 Tahun 2002 tentang Pembentukan Tim Peneliti Pemekaran Kabupaten Ketapang; dengan penanggungjawab tim adalah Bupati Ketapang (H. Morkes Effendi, S.Pd, $\mathrm{MH})$ dan sebagai wakil penanggungjawab adalah Wakil Bupati Ketapang (Lorentius Majun, SH). Tim kajian penelitian awal ini dibentuk untuk mengkaji terkait kriteria potensi daerah, potensi ekonomi, sosial budaya, sosial politik, kependudukan, luas daerah dan kriteria lain yang ada pada calon Daerah Otonom Baru (DOB);

b) Menyusun kajian penelitian awal kerjasama dengan lembaga/ perguruan tinggi yang ditunjuk. Sesuai dengan Surat Bupati Ketapang nomor 100/0671/Tapem bahwa perguruan tinggi yang ditunjuk untuk melakukan kajian penelitian awal ini adalah Pusat Pengembangan dan Profesi Universitas Indonesia (UI); dan

c) Pengesahan oleh Bupati dan DPRD. Pembahasan tim penelitian awal rencana pemekaran daerah Kabupaten Kayong Utara dengan DPRD Kabupaten Ketapang pada tanggal 14 Oktober 2003; dan Rapat Paripurna DPRD Kabupaten Ketapang pada tanggal 16 Oktober 2003. Hasil pembahasan pada kedua agenda rapat tersebut menghasilkan satu kesepakatan bersama antara Pemerintah Kabupaten Ketapang dan DPRD Kabupaten Ketapang yang pada hakikatnya menyetujui terhadap rencana pembentukan Kabupaten Kayong Utara. Hasil kesepakatan tersebut dituangkan kedalam Surat Keputusan DPRD 
Kabupaten Ketapang Nomor 15 tahun 2003 tentang Persetujuan Dewan Perwakilan Rakyat Daerah Kabupaten Ketapang terhadap Rencana Pembentukan Kabupaten Kayong Utara pada tanggal 16 Oktober 2003.

\subsubsection{Pemerintah Provinsi Kalimantan Barat}

Gubernur Kalimantan Barat menindaklanjuti usulan pemekaran ke DPRD Provinsi dengan Surat Gubernur Kalimantan Barat Nomor 125.1/3588/Pem-B yang isinya menjelaskan bahwa berdasarkan kajian administratif, pemekaran tersebut telah memenuhi syarat dan selanjutnya DPRD Provinsi Kalimantan Barat dapat memproses lebih lanjut usulan dimaksud yang dituangkan dalam Surat Keputusan DPRD Provinsi Kalimantan Barat. Langkah selanjutnya berdasarkan surat tersebut, DPRD Provinsi Kalimantan Barat membentuk tim yang akan melaksanakan peninjauan langsung ke daerah pemekaran.

Tim yang melaksanakan peninjauan lapangan adalah Tim Komisi A DPRD Provinsi Kalimantan Barat. Kegiatan tersebut dilaksanakan pada tanggal 15 Desember 2003 dan hasilnya dari kegiatan tersebut akan disampaikan kepada Pimpinan dan seluruh anggota DPRD pada Rapat Paripurna untuk membahas kelanjutan dari pemekeran Kabupaten Kayong Utara. Rapat Paripurna ke VII masa persidangan IV dilaksanakan pada tanggal 17 Desember 2003 yang dihadiri oleh pihak eksekutif dan legislatif. Hasil dari rapat tersebut menghasilkan Keputusan Dewan Perwakilan Rakyat Daerah Provinsi Kalimantan Barat Nomor 13 Tahun 2003 yang pada dasarnya menyetujui atas usul pemekaran daerah Kabupaten Ketapang menjadi dua Kabupaten, yaitu Kabupaten Ketapang dan Kabupaten Kayong Utara.

\subsection{Kinerja Pemerintah Kabupaten Kayong Utara Pasca Pemekaran Daerah}

Untuk melihat bagaimana kinerja Pemerintah Kabupaten Kayong Utara dalam mewujudkan hasil tersebut dapat dilihat berdasarkan tiga indikator kinerja yang juga digunakan pada Studi Evaluasi Pemekaran Daerah oleh BAPPENAS bekerjasama dengan United National Development Program (UNDP) pada Tahun 2007, yaitu sebagai berikut:

\subsubsection{Kinerja Perekonomian Daerah}

Produk Domestik Regional Bruto (PDRB) merupakan salah satu indikator penting untuk mengetahui kondisi ekonomi di suatu daerah dalam suatu periode tertentu, baik atas dasar harga berlaku maupun atas dasar harga konstan. Rentang Tahun 2008-2013, nilai pembentuk PDRB Kabupaten Kayong Utara selalu mengalami peningkatan. Nilai tersebut pada Tahun 2008 berjumlah 399 milyar rupiah dan pada Tahun 2013 nilai tersebut bertambah menjadi 518 milyar rupiah. Sektor pertanian merupakan sektor terbesar penyumbang pembentukan PDRB Kabupaten Kayong Utara. Sektor pertanian didominasi oleh jenis tanaman bahan makanan, perikanan dan kehutanan. Selain sektor pertanian, sektor industri pengolahan dan jasa-jasa juga merupakan sektor terbesar penyumbang pembentukan PDRB. Sektor industri pengolahan didominasi oleh industri pengolahan kayu dan hasil hutan (Industri non migas) sedangkan sektor jasa jasa didominasi oleh jasa dari pemerintahan umum. Bappenas (2007) mengemukakan bahwa rata-rata sektor pertanian merupakan komponen terbesar dalam struktur pembentukan PDRB pada Daerah Otonom Baru (DOB).

Selanjutnya pada indikator laju pertumbuhan ekonomi dapat dilihat bahwa laju pertumbuhan ekonomi Kabupaten Kayong Utara relatif lebih stabil jika dibandingkan dengan kabupaten induknya, yaitu Kabupaten Ketapang dan Provinsi Kalimantan Barat. Laju Pertumbuhan tersebut bergerak antara 5-6\% setiap tahunnya. Pertumbuhan ekonomi Kabupaten Kayong Utara ditopang oleh sektor primer yang berhubungan langsung dengan pengelolaan sumber daya alam seperti sektor pertanian, sektor perikanan dan sektor kehutanan. Selain itu, pendapatan per kapita masyarakat di Kabupaten Kayong Utara pada rentang Tahun 20082017 selalu menunjukkan peningkatan signifikan yang artinya semakin tinggi Produk Domestik Regional Bruto (PDRB) perkapita, maka semakin tinggi tingkat perekonomian wilayah dan semakin maju. Peningkatan tersebut disebabkan oleh bertambahnya nilai Produk Domestik Regional Bruto (PDRB) Kayong Utara. Pendapatan per kapita Kabupaten Kayong Utara masih berada di bawah rata-rata pendapatan per kapita Provinsi Kalimantan Barat.

\subsubsection{Kinerja Keuangan}

Tingkat ketergantungan fiskal Pemerintah Kabupaten Kayong Utara pasca pemekaran daerah masih tinggi. Tingkat ketergantungan fiskal paling tinggi terjadi pada Tahun 2013 dan Tahun 2016, yaitu berada di angka 40-44\% dari jumlah penerimaan daerah. Studi Bappenas bersama United National Development Programs (UNDP) Tahun 2007 juga mengungkapkan bahwa jika dibandingkan dengan daerah induknya, tingkat ketergantungan fiskal daerah pemekaran lebih tinggi. Hal ini sekali lagi menunjukkan fakta bahwa daerah pemekaran bukanlah daerah yang secara cepat siap mengambil alih fungsi penerimaan daerah.

Selanjutnya Rentang 2008-2012 rata-rata Pendapatan Asli Daerah (PAD) Kabupaten Kayong Utara mampu tumbuh 2 kali lipat setiap tahunnya, tetapi pada Tahun 2013 terjadi penurunan PAD terutama pada pendapatan pajak daerahnya yang turun hingga $70 \%$ dari pendapatan pajak daerah Tahun 2012. Namun demikian, peranan Pendapatan Asli Daerah (PAD) terhadap total 
penerimaan masih relatif masih rendah hal ini dapat dilihat dari ratio PAD terhadap total penerimaan daerah, dimana peranannya masih sekitar $1-7 \%$ dengan perkembangannya dari tahun ke tahun relatif meningkat yang artinya Pemerintah Kabupaten Kayong Utara berusaha untuk meningkatkan kemandirian fiskalnya melalui peningkatan jumlah PAD setiap tahunnya.

\subsubsection{Kinerja Pelayanan Publik}

Kebijakan Pemerintah Kabupaten Kayong Utara dengan menambah sarana dan prasarana sekolah baru dan menggratiskan biaya sekolah baik dari tingkat Sekolah Dasar (SD), Sekolah Menengah Pertama (SMP), dan Sekolah Menengah Atas (SMA) berdampak kepada hal yang positif. Motivasi masyarakat untuk mengenyam pendidikan menjadi bertambah, ini terlihat dengan bertambahnya jumlah siswa dari Tahun 2008-2017. Pertambahan jumlah siswa yang paling signifikan terlihat pada jenjang SMA, yaitu pada Tahun 2008 jumlah siswanya hanya berjumlah 1.187 orang dan bertambah menjadi 3.723 orang pada Tahun 2017. Pertambahan jumlah siswa juga dilihat dari jenjang pendidikan SMP, yaitu pada Tahun 2008 jumlah siswa berjumlah 3.207 orang dan bertambah menjadi 5.862 orang pada Tahun 2017.

Sejak dimekarkan menjadi Daerah Otonom Baru (DOB) pada Tahun 2007 sampai dengan sekarang, Kabupaten Kayong Utara belum memiliki fasilitas rumah sakit. Hal ini juga berpengaruh terhadap kinerja pelayanan publik Pemerintah Kabupaten Kayong Utara khsususnya di bidang kesehatan. Untuk pelayanan publik dirumah sakit, masyarakat setempat baru bisa mendapatkannya didaerah induk, yaitu Kabupaten Ketapang. Keterbatasan anggaran dalam APBD Kabupaten Kayong Utara merupakan salah satu penyebab belum adanya Rumah Sakit Umum Daerah (RSUD). Rencana pembangunan rumah sakit sudah ada sejak Tahun 2012 yang disertai dengan studi banding dibeberapa daerah. Hasilnya pada Tahun 2017, pemerintah pusat melalui Kementerian Kesehatan menyetujui pembangunan rumah sakit di Kabupaten Kayong Utara. Pembangunan rumah sakit tersebut dibangun dari dana bantuan Kementerian Kesehatan dengan menggunakan Dana Alokasi Khusus (DAK) bidang kesehatan dengan anggaran sebesar 43 miliar rupiah. Dengan telah berdirinya rumah sakit ini, tentu diharapakan dapat memberikan peningkatan pelayanan kesehatan dengan baik kepada masyarakat.

\subsection{Optimalisasi Peran dan Fungsi Pemerintah dalam Pemekaran Daerah}

Dalam pengoptimalisasian peran dan fungsi pemerintah dalam pemekaran daerah, Kabupaten Kayong Utara memiliki program unggulan antara lain Program Pelayanan Administrasi terpadu Kecamatan (PATEN).
Program PATEN ini merupakan salah satu program yang menitikberatkan kecamatan sebagai garda terdepan dalam meningkatkan fungsi pelayanan baik yang meliputi bidang perizinan dan non perizinan. Selanjutnya adalah dengan Membentuk Perusahaan Daerah Air Minum (PDAM) dengan Peraturan Bupati Kayong Utara Nomor 22 Tahun 2012 tentang Pembentukan Organisasi Perusahaan Daerah Air Minum (PDAM) Kabupaten Kayong Utara.

Selain itu Pemerintah Kabupaten Kayong Utara melaksanakan kebijakan sekolah gratis dalam meningkatkan pelayanan dalam bidang jasa. Dasar hukum pelaksanaan kebijakan ini adalah, Peraturan Daerah (PERDA) Kabupaten Kayong Utara Nomor 5 Tahun 2014 tentang Pendidikan Gratis. Kebijakan pendidikan gratis dengan full cover (seluruh biaya ditanggung sepenuhnya oleh Pemerintah Kabupaten Kayong Utara). Pada Tahun 2011, Pemerintah Kayong Utara menyiapkan dana sebesar 114 milyar dari total APBD Kayong pada saat itu sebesar 390,8 milyar. Anggaran untuk sektor pendidikan tersebut bersumber dari Pemerintah Pusat sebesar 71,45 milyar, bantuan Pemerintah Provinsi Kalbar sebesar 6,2 milyar dan APBD Kabupaten Kayong Utara sebesar 36,35 milyar.

Program lainnya yang menjadi kebijakan dalam mengoptimalkan peran dan fungsi Pemerintah Kabupaten Kayong Utara adalah Program 10 sarjana per desa. Program ini adalah program beasiswa yang dikhususkan untuk mencetak Sarjana (S1). Program ini mulai dilaksanakan oleh Pemerintah Kabupaten Kayong Utara dari Tahun 2014 dan diharapkan dapat meningkatkan kualitas sumber daya manusia dan mengurangi ketergantungan terhadap pemerintah di masa depan.

\section{Kesimpulan}

Berdasarkan hasil penelitian dan pembahasan yang telah diuraikan mengenai proses pemekaran dan kinerja Pemerintah Kabupaten Kayong Utara pasca pemekaran daerah, dapat ditarik beberapa kesimpulan sebagai berikut:

a) Proses Pembentukan Daerah Otonomi Baru (DOB) Kabupaten Kayong Utara dengan memaksimalkan mekanisme Hak Inisiatif DPR;

b) Pasca pemekaran daerah, kinerja perekonomian dan kinerja pelayanan publik selalu meningkat setiap tahunnya, sedangkan untuk kinerja keuangan Kabupaten Kayong Utara masih rendah. Hal tersebut disebabkan tingkat ketergantungan fiskalnya terhadap dana perimbangan, khususnya Dana Alokasi Umum (DAU) masih tinggi serta tingkat kemandirian fiskal masih rendah. Belum optimalnya peran Pendapatan Asli Daerah (PAD) terhadap total penerimaan daerah setiap tahunnya adalah salah satu penyebab utama masih rendahnya kemandirian fiskal Pemerintah Kabupaten Kayong Utara; dan 
c) Optimalisasi peran dan fungsi pemerintah dalam pemekaran daerah baik dalam peningkatan fungsi pelayanan (public service), fungsi pengaturan (regulation), fungsi pemberdayaan (empowerement) mengalami peningkatan:

- Fungsi Pelayanan dengan melaksanakan program Pelayanan Administrasi Terpadu Kecamatan (PATEN), pembentukan Perusahaan Daerah Air Minum (PDAM), Kebijakan sekolah gratis dari jenjang SD, SMP dan SMA.

- Fungsi pengaturan dengan membuat Peraturan Daerah (PERDA) sesuai dengan kewenangan daerah yang diatur dalam Undang-Undang sebanyak 80 Peraturan Daerah kurun waktu 20112016.

- Fungsi pemberdayaan dengan melaksanakan Program 10 Sarjana per Desa yang merupakan pemberian beasiswa untuk jenjang sarjana kepada putra-putri daerah di Kabupaten Kayong Utara.

\section{Daftar Pustaka}

Adamolekun, L. (1986). Politics and Administration in Nigeria. Ibidan, Nigeria: Spectrum Books.

Domai, Tjahjanulin. (2011). Sound Governance. Malang: UB Press.

Dwiyanto, Agus et al. (2002). Reformasi Birokrasi Publik di Indonesia. Pusat Studi Kependudukan dan Kebijakan-UGM, Yogyakarta.

Djayasinga, Marselina. (2006). Ekonomi Publik Suatu Pengantar. Universitas Lampung, Bandar Lampung.

Ferrazzi, Gabriele. (2008). Special Autonomy: A Common Form of Asymmetric Decentralization. Paper for Aceh Workshop, November 19, 2008.

Hamzah, Muhammad Zilal. (2008). Kajian Teori Desentralisasi Fiskal. Jakarta: LPS STIEBI.

Manan, Bagir. (1994). Hubungan Antara Pusat dan Daerah Menurut UUD 1945. Jakarta: Sinar Harapan.

Miles, M.B, Huberman, A.M., \& Saldana, J. (2014). Qualitative Data Analysis, A Methods Sourcebook, Edition 3. USA: Sage Publications Inc.

Poerwadarminta. (2005). Kamus Umum Bahasa Indonesia Edisi Ketiga. Jakarta: Balai Pustaka.

Riani, Asri Laksmi. (2012). Manajemen SDM Masa Kini. Yogyakarta: Graha Ilmu.

Ratnawati, Tri. (2009). Pemekaran Daerah dan Beberapa Isu Terseleksi. Yogyakarta: Pustaka Pelajar.

Sugiyono. (2011). Metode Penelitian Kombinasi (Mixed Method). Bandung: Alfabeta.

Swianiewicz, Pawel. (2002). Consolidation or Fragmentation? The Size of Local Governments in Central and Eastern Europe. Open Society Institute, Budapest.
Wibowo. (2007). Manajemen Kinerja. Jakarta: PT. Raja Grafindo Parsada. 